Recently it was supposed, apparently, that the whole country was pressing for the 80 per cent., which some people indeed thought was a better bread. Folk had complained in the past of being upset by wholemeal flour, but it must be realized that the position is now quite different; the 85 per cent. extraction flour was a very beautiful and wonderfully chosen foodstuff. It had practically no fibre; it was medically proved that it was nonirritant even to people with ulcers. It must be admitted, however, that there are differences induced by different ways of baking. I am bound to say that when we baked it at home for one year it was excellent, and it is curious that I have never elsewhere tasted bread baked from 85 per cent. extraction flour as good as that baked in the home! At present we have not got that choice to which $I$ have just referred. If we wish to get 85 per cent, apparently we cannot do so. We are, in a moment, going to listen to our friends on these subjects and I would like to remind them and you that some of us who have been drilled into a biological frame of mind over many years will require a deal of convincing that it is nutritionally sound to drop the wheat germ from the diet. Forty years ago, Hopkins (1906) wrote:

". . no animal can live upon a mixture of pure protein, fat and carbohydrate, and even when the necessary inorganic material is carefully supplied the animals still cannot flourish. The animal body is adjusted to live either upon plant tissues or the tissues of other animals, and these contain countless substances other than the proteins, carbohydrates, and fats. Physiological evolution, I believe, has made some of these well-nigh as essential as are the basal constituents of diet ...".

I know that those who have a more purely chemical discipline often feel that it is illogical for biologists to believe in the value of unknown substances but, if you continue to work on these matters for some years, you do approximate to Hopkins' opinion and you become certain that there are valuable substances, present in a complex material such as wheat, of which you do not yet know, and you would prefer to be on the safe side when responsible for advice.

REFERENCE

Hopkins, F. G. (1906). Analyst, 31, 385.

\title{
The Composition and Milling of Wheat
}

\section{Dr. R. A. McCance and Dr. E. M. Widdowson (Department of Medicine, Cambridge)}

Wheat is not a substance of fixed and invariable composition, and it is well known to vary with the species, season and locality. In point of fact these differences are most important, and determine to a large extent the uses to which wheat shall be put. Manitoba wheat contains more protein than English wheat, and less carbohydrate and water. There are also differences in the mineral and vitamin content. Thus Manitoba wheat tends to contain more vitamin $B_{1}$, but less calcium, than English wheat, whereas both wheats have about the same amount of phosphorus, 
and give rise to the same number of calories when they are consumed (McCance, Widdowson, Moran, Pringle and Macrae, 1945).

Figures for whole wheat give no idea of the composition of the several parts of the grain. Such figures are, indeed, averages of the most dangerous sort and, to some extent, they are really things of the past for it is clear that from now on the demand will be for analyses of the component parts of the wheat berry. Figure 1 shows a diagrammatic

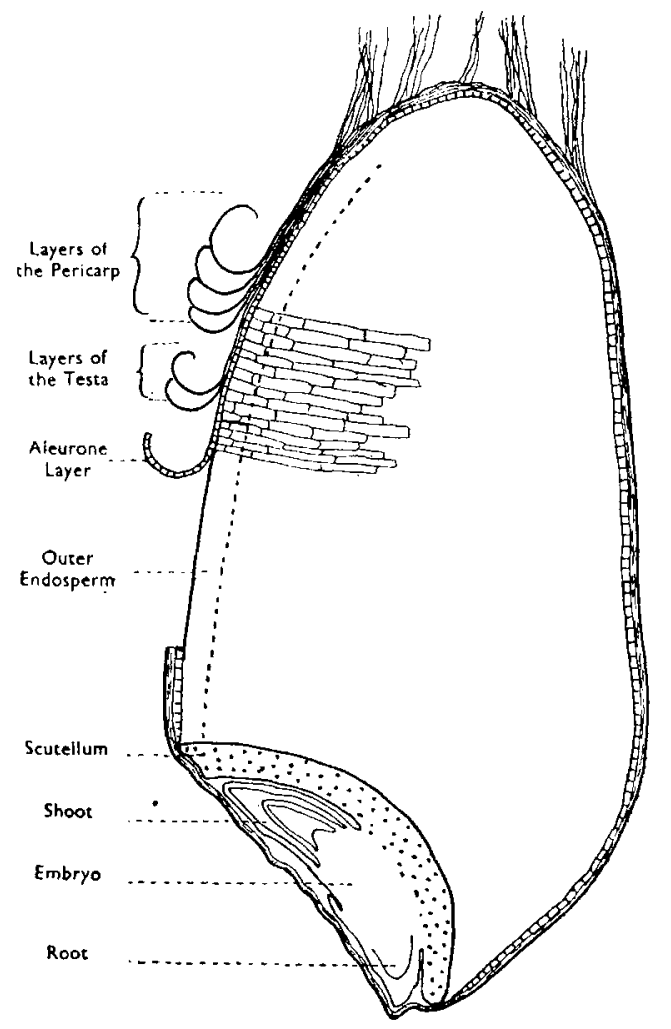

Figdre 1. Longitudinal Section of Whrat Gram.

section of a grain of wheat and Table 1 the proportions which the various parts contribute to the weight of the whole. Table 2 shows the composition of some of the parts of the wheat berry, and the values for the whole grain have been added for comparison. In Tables 1 and 2 the figures, some of which should be regarded at present as approximations, have mostly been taken from the publications of the Cereals Research Station at St. Albans (Halton and Barton-Wright, 1943; Hinton, 1944; Moran, 1945), and very high praise must be given to the work which is being turned out at present by that very competent team of investigators. A glance at Table 2 shows that the inner parts of the endosperm are much poorer in protein, minerals and vitamins than the outer layers. The quantities of fat and protein in the germ require no emphasis and the voL. 4,1946$]$ 
amounts of phosphorus and vitamin $B_{1}$ in the scutellum are really remarkable. One cannot help wondering whether these substances are not metabolically as well as anatomically associated. No figures seem

TABLE 1

Component Parts of the Wheat Grain as Perceintages of the Whole

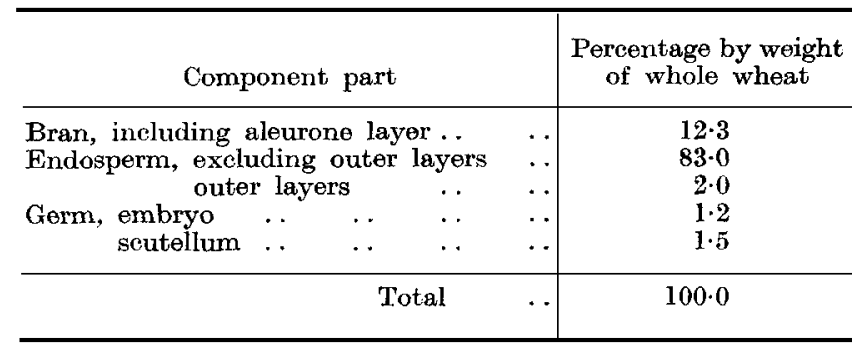

TABLE 2

Composition of the Whole Wheat Grain, the Endosperm and the Germ

\begin{tabular}{|c|c|c|c|c|c|}
\hline \multirow[b]{2}{*}{ Constituent } & \multirow[b]{2}{*}{$\begin{array}{l}\text { Whole } \\
\text { wheat }\end{array}$} & \multicolumn{2}{|c|}{ Endosperm } & \multicolumn{2}{|c|}{ Germ } \\
\hline & & $\begin{array}{l}\text { Central } \\
\text { portions }\end{array}$ & $\begin{array}{l}\text { Outer } \\
\text { layers }\end{array}$ & Embryo & Scutellum \\
\hline Protein, per cent. & $8 \cdot 9$ & $8 \cdot 1$ & $14 \cdot 6$ & 33 & 29 \\
\hline Fat, per cent. & $2 \cdot 2$ & $0 \cdot 7$ & - & 15 & 30 \\
\hline Carbohydrate, per cent. & $66 \cdot 8$ & $75 \cdot 8$ & -. & - & \\
\hline Phosphorus, mg. per $100 \mathrm{~g}$. . & 311 & 59 & 1017 & 1160 & 1900 \\
\hline Phytate phosphorus, mg. per & & & & & \\
\hline $100 \mathrm{~g} . \quad \ldots$ & 213 & 8 & 874 & 400 & 1300 \\
\hline Iron, mg. per $100 \mathrm{~g}$. & $3 \cdot 0$ & 0.5 & 12 & 9 & $\ldots$ \\
\hline Vitamin $B_{1}$, I.U. per g. & $1 \cdot 6$ & $0 \cdot 1$ & $1 \cdot 8$ & $3 \cdot 0$ & 60 \\
\hline Riboflavin, $\mu$ g. per g. & 1.5 & 0.4 & 1.8 & 15 & $\ldots$ \\
\hline Nicotinic acid, $\mu$ g. per g. & 42 & $5 \cdot 0$ & 184 & 60 & - \\
\hline
\end{tabular}

to be available for the aleurone layer, but it is known to be extremely rich in protein and fat, and even the bran itself, which is generally regarded as being of more use as a laxative than as a food, seems to contain even more nicotinic acid than the outer endosperm (Moran, 1945).

Milling may be defined broadly as the process by which the grains of wheat are converted into flour. In the earliest days the process was undoubtedly the simple one of grinding, and this is of course all that is required to convert grains of wheat into wholemeal flour but, for centuries now, the demand from the bakers and consumers has been for a white loaf, and very early the millers began to accede to this request by removing the bran which is the most highly coloured component of the wheat. Milling is a very complicated process and no two mills work in exactly the same way. The basic principle in all is the same, to separate the white endosperm, which bakes well, from the coloured bran which does not but, for physical reasons, it is hard to get rid of all the bran without also getting rid of the aleurone layer, the outer endosperm and the germ. Consequently, the white flour which was being produced before the war consisted almost entirely of endosperm. As a source of calories it was 
good, but as a source of minerals, vitamins and balanced amino-acids it was bad. When the Government decreed that 85 per cent. of the wheat grain must be eaten by the people in this country instead of some 70 per cent. which had been customary before the war, the millers were confronted with a very pretty problem. The specifications for the new flour (Lister Institute and Medical Research Council, 1941) asked the millers to remove as much of the bran as possible, and to retain the germ, a high proportion of the $B$ vitamins, and the protein in the outer layers of the grain. It was out of the question to effect an absolutely clean separation, for some powdered bran inevitably got into the flour, and the aleurone layer and most of the outer endosperm separated with the bran. Nevertheless, the millers succeeded reasonably well even at first and the provision of National wheatmeal flour not only saved the country a great deal of shipping but also provided the people with a much more nutritious bread than they had been eating before the war (Lepkovsky, 1944).

A series of flours of various extractions and the whole wheats from which they had been milled were analysed in 1942, 1943 and 1944 (McCance et al., 1945) and they give a general idea of the way in which the various nutrients separate out as the extraction of the flour is changed, but it must be realized that the figures are not final. Milling technique can be improved and has already been improved since these analyses were made, so that more and more of the germ and outer endosperm could be included in the parts of the wheat used for human consumption, and less and less of the bran.

Some months ago the percentage of wheat to be used for human consumption was reduced to $82 \cdot 5$, and still more recently to 80 . Quite frankly, we consider that in doing this the Government made a mistake. Nutritionally the country has suffered, and will suffer more still if the extraction is further reduced. He would be a very bold man who offered to replace by enrichment all the valuable amino-acids, minerals and vitamins that are to be found in those "mighty atoms", the embryo, the scutellum and the outer endosperm.

Whatever the Government of 1945 decides to do about the extraction of wheat, the knowledge which has been and is being amassed about the composition and milling of wheat will stand the world in good stead in the future. In times of plenty we may be able to afford to give all the best parts of the wheat to our animals and to eat the poorer parts ourselves, but whenever wheat is short, or money is short, and this may be the deciding factor in the years to come, the percentage of the berry to be used for human consumption will be high. During the wheat shortage of 1795 a Committee of Merchants, Bankers and Traders (1795) recommended that all who could should use a flour "which shall be the whole produce of the grain, the bran only excepted", and history will repeat itself once more whenever this country has to face its next crisis. But that is not the whole story. In so far as we are responsible for the nutrition of native races, it is our duty to see that they are provided with the best possible flour for human consumption. They need it even more than we do, and the knowledge and experience which is being acquired as the direct result of this war should enable us to see that they get it.

voL. 4,1946$]$ 
REFERENCES

Committee of Merchants, Bankers and Traders (1795). An Address to the Public. London: James Phillips. (See Vancouver, John. Cambridge University Library. Bbb. 24. 51.)

Halton, P. and Barton-Wright, E. (1943). J. Soc. chem. Ind. 62, 123.

Hinton, J. J. C. (1944). Biochem. J. 38, 214.

Lepkovsky, S. (1944). Physiol. Rev. 24, 239.

Lister Institute and Medical Research Council. Accessory Food Fuctors Com. mittee (1941). Lancet, 240, 703.

McCance, R. A., Widdowson, E. M., Moran, T., Pringle, W. J. S. and Macrae, T. F. (1945). Biochem. J. 39, 213.

Moran, T. (1945). Nature, Lond., 155, 205.

\section{Nutritive Value of Proteins Contained in Wheat Flours of Different Degrees of Extraction}

Dr. H. Chick (Division of Nutrition, Lister Institute, London, S.W.1)

The nitrogenous substances in wheat are almost entirely in the form of protein, the non-protein nitrogenous materials being small in amount and not usually amounting to more than about 5 per cent. of the total. The proteins contained in the different parts of the grain differ in both quantity and quality.

\section{Quantity of Proteins}

Table 1 taken from Osborne and Mendel (1919), and founded on the work of Girard (1884), shows the endosperm to be the fraction poorest in protein. The germ, though containing 30 per cent. of protein, is only about 2 per cent. of the grain, and thus makes a relatively small contribution to the total nitrogen. The bran, comprising 15 per cent. of the

TABLE 1

Protein Content of Fractions of the Wheat Grain

(Protein content $(\mathrm{N} \times 5.7)$ of whole grain 12.5 per cent.)

(From Girard, 1884, and Osborne and Mendel, 1919)

\begin{tabular}{|c|c|c|c|}
\hline \multirow[b]{2}{*}{ Fraction } & \multirow[b]{2}{*}{$\begin{array}{l}\text { Percentage by } \\
\text { weight of } \\
\text { grain }\end{array}$} & \multicolumn{2}{|c|}{ Protein in fraetion } \\
\hline & & Per cent. & $\begin{array}{l}\text { As percentage of } \\
\text { total protein } \\
\text { in grain }\end{array}$ \\
\hline Endosperm & $83 \cdot 5$ & $11 \cdot 1$ & $73 \cdot 3$ \\
\hline Bran & $15 \cdot 0$ & $18 \cdot 7$ & $22 \cdot 3$ \\
\hline Germ & $1 \cdot 5$ & $36 \cdot 7$ & $4 \cdot 4$ \\
\hline
\end{tabular}

weight of the grain, contains more than one-fifth of the total protein; this is due to the cells of the aleurone layer which, though morphologically the outer layer of the endosperm, is firmly adherent to the pericarp and is not separated in the ordinary processes of milling. According to Girard the aleurone layer forms about two-thirds of the weight of the bran and contains three-quarters of its nitrogen; or 16 per cent. of the total protein of the grain. The loss of nitrogen in the offals during milling of wheat to white flour is thus a serious one. 